\title{
STANDARD-SETTERS VERSUS BIG4 OPINION, CONCERNING IASB REVISION PROJECT OF THE CONCEPTUAL FRAMEWORK FOR FINANCIAL REPORTING. THE CASE OF PRESENTATION AND DISCLOSURES CHAPTER
}

\author{
Burca Valentin, PhD Student \\ West University of Timisoara \\ Mates Dorel, PhD Professor \\ West University of Timisoara \\ Puscas Adriana, PhD Lecturer \\ Vasile Goldis University, Arad
}

(Received April 2015; accepted June 2015)

\begin{abstract}
On the last decades the accounting system haven't been able to follow the dynamics of the economic systems generated by the globalization process. In order to reduce the lag between the demand of financial information and the offer of financial information, IASB has started numerous initiatives aiming the increase on the quality of the financial information. Among the current list of current IASB major projects there is also the project of revising the actual conceptual framework for financial reporting. This study is designed to give some directions that will be considered on the exposure draft of this project, analyzing the comment letters submitted by the members of ASAF and the Big4 as well. The study reveals the increasing importance the preparers and users give to the disclosures included on the notes to the primary financial statements. Moreover, on this study we emphasize several challenges that IASB has to face on issuing the exposure draft for this important project. Some of the main challenges refer to the narrow scope of the financial statements, the criteria used on classification, aggregation and offsetting, or the use of the materiality concept.
\end{abstract}

Key words: IFRS, convergence, standard-setting, deferral, revenue.

JEL Classification: G33, M21, M40, M41.

\section{Introduction}

Along the globalization process entire financial reporting supply chain has encountered significant changes that determined researchers to debate paradigms concerning minimum level of financial reporting regulation, the objectives of the financial statements, or the potential conflict-states between accounting principles and qualitative characteristics of financial information.

The real problem with financial reporting today is rather complexity, than the quality or the volume of financial information disclosed. Even more, we consider that complexity in financial reporting is actually a cause for less qualitative 
Burca, V., Mates, D., Puscas, A., (2015)

Standard-setters versus Big4 opinion, concerning IASB revision project of the conceptual framework for financial reporting. The case of presentation and disclosures chapter

financial information, or the increase of redundant and irrelevant disclosed financial information.

Financial information quality is more important than the volume disclosed, but is constrained by financial statements complexity, affecting seriously their understandability. That is why on the literature it is underlined the opportunity that the financial reporting strategies have to choose an integrated financial reporting approach. This way, disclosed financial information is based on a triple bottom line approach, describing economic, social and environmental information in such way shareholders' value is fairly reported (IIRC, 2013). The issue is that sometimes reporting entities use this opportunity to mislead the users of financial information and transform their annual report on a strong marketing tool through different impression management techniques (Pompian, 2006).

Moreover, national environment particularities and business model uniqueness raise serious challenges on the current international accounting convergence process, generating difficulties for managers to disclose on the financial statements a true and fair view of the financial situation of a reporting entity. Multiple accounting choices, regulated by international accounting standards and national accounting regulation as well, generate accounting treatment differences, affecting drastically financial information comparability. On these circumstances, the role of financial reporting incentives becomes central; even we talk about high quality accounting regulation and institutional enforcement efficiency (Christensen et. al., 2014).

On the other side, researchers and practitioners efforts aiming simplification of financial reports have to be cautiously analyzed as there are serious difficulties in financial structures recognition and aggregation. This is because at the base of accountants' judgment stay different threshold criteria such as the probability of economic benefits generated in case of assets recognition. Such issues determine value relevance deterioration in case financial information is excessively detailed in the financial statements, or the accounting principles are wrong interpreted. Thus, offsetting elements of financial statements, using conditional accounting conservative treatments on earnings recognition, practicing real activity earnings management, using different measurement without linking to the business model will negatively impact the value relevance of the financial information, creating a fall between accounting-based covenants and market-based covenants. Unless these topics will not be limited by the accounting regulation, or internal audit mechanisms, information asymmetry will persist between shareholders, managers and creditors, leading to positive impact on manager's compensation and negative impact on entity's financing decision (Armstrong et. al., 2010).

From EFRAG point of view, the problem of complexity is just a matter of balancing the need of understandability of the financial information disclosed for 
Burca, V., Mates, D., Puscas, A., (2015)

Standard-setters versus Big4 opinion, concerning IASB revision project of the conceptual framework for financial reporting. The case of presentation and disclosures chapter

the users, and the cost constraints implied by a growing volume of information
disclosed from prepares' perspective (EFRAG, 2014).

Table 1. Causes of complexity in financial reporting

\begin{tabular}{|c|c|}
\hline Complex activities & $\begin{array}{l}\text { The increasingly sophisticated nature of business transactions can be difficult to } \\
\text { understand, particularly with respect to the growing scale and scope of companies with } \\
\text { operations that cross international boundaries and financial reporting regimes. }\end{array}$ \\
\hline $\begin{array}{l}\text { Incomparability and } \\
\text { inconsistency }\end{array}$ & $\begin{array}{l}\text { Incomparable reporting of activities within and across entities arises because of factors } \\
\text { such as the mixed attribute model, bright lines, and exceptions to general principles. } \\
\text { Some accounting guidance permits the structuring of transactions in order to achieve } \\
\text { particular financial reporting results. Further, to the extent new pronouncements are } \\
\text { adopted prospectively, past and present periods of operating results are not } \\
\text { comparable. This is compounded by the rapid pace at which new accounting } \\
\text { pronouncements are being adopted, which hinders the ability of all constituents to } \\
\text { understand and apply new guidance in relatively short time frames. }\end{array}$ \\
\hline $\begin{array}{l}\text { Nature of financial } \\
\text { reporting standards }\end{array}$ & $\begin{array}{l}\text { Standards can be difficult to understand and apply for several reasons, including: } \\
\text { - the existence of opposing points of view that were taken into account when } \\
\text { developing standards - most importantly, the attempts by public companies to smooth } \\
\text { amounts that vary from period to period, versus the requests from those who want such } \\
\text { amounts recorded as incurred; } \\
\text { - the challenge of describing accounting principles in simple terms (i.e., plain English) } \\
\text { for highly sophisticated transactions; } \\
\text { - the presence of detailed guidance for numerous specific fact patterns; } \\
\text { - the development of standards on the basis of an incomplete and inconsistent } \\
\text { conceptual framework; }\end{array}$ \\
\hline Volume & $\begin{array}{l}\text { The vast number of formal and informal accounting standards, regulations, and } \\
\text { interpretations, including redundant requirements, make finding and evaluating the } \\
\text { appropriate standards and interpretations challenging for particular fact patterns }\end{array}$ \\
\hline $\begin{array}{l}\text { Audit and regulatory } \\
\text { systems that } \\
\text { complicate the use } \\
\text { of professional } \\
\text { judgment }\end{array}$ & $\begin{array}{l}\text { The risk of litigation and the fear of being "second-guessed" result in: } \\
\text { - a greater demand for detailed rules on how to apply accounting standards to an ever- } \\
\text { increasing set of specific situations; } \\
\text { - unnecessary restatements that are not meaningful to investors; } \\
\text { - legalistic disclosures that are difficult to understand; }\end{array}$ \\
\hline $\begin{array}{l}\text { Educational } \\
\text { shortcomings }\end{array}$ & $\begin{array}{l}\text { Undergraduate and graduate education in accounting has traditionally emphasized the } \\
\text { mechanics of double-entry bookkeeping, which favors the use of detailed rules rather } \\
\text { than the full understanding of relevant principles. The same approach is evident in the } \\
\text { certified public accountant (CPA) exam, as well as continuing professional education } \\
\text { requirements. }\end{array}$ \\
\hline Information delivery & $\begin{array}{l}\text { The need for information varies by investor type and is often driven by legal risk, } \\
\text { rather than investor needs. In addition, the lack of a holistic approach to disclosures, } \\
\text { the amount and timing of information, and the method by which it is transmitted, may } \\
\text { result in complex and hard-to-navigate disclosures that cause investors to sort through } \\
\text { material that they may not find relevant in order to identify pieces that are. These } \\
\text { factors make it difficult to distinguish the sustaining elements of an entity from non- } \\
\text { operating or other influences. }\end{array}$ \\
\hline
\end{tabular}

Source: Final Report of the Advisory Committee on Improvements to Financial Reporting to the United States Securities and Exchange Commission, cited by Eccles \& Krzus (2010), One Report. Integrated Reporting for a Sustainable Strategy, Wiley

\section{Until issues such as the subjective estimates use, exceptions on applying accounting principles, or arbitrary classification will not be solved, preparers will}


Burca, V., Mates, D., Puscas, A., (2015)

Standard-setters versus Big4 opinion, concerning IASB revision project of the conceptual framework for financial reporting. The case of presentation and disclosures chapter

be tempted to use these breaches on their interest and mislead the users of the financial information into wrong direction by disclosing large volumes of irrelevant information.

Even Hans Hoogervorst, Chairman of the IASB, claimed that: it has become increasingly clear that we are suffering from disclosure overload. However, there are many reasons why this is the case. Standard-setters are not blameless, but neither are preparers, auditors or regulators. So, the idea is to get everybody in a room and see what we can do to address this topic. However, no one should expect quick wins. One investor's disclosure clutter is another investor's golden nugget of information. Taking information away is never easy. We will proceed with caution, and build upon the impressive work that has already been done by others in this area (IASB, 2012).

Current process of international accounting convergence is trying to respond properly to all financial reporting issues, by designing a core set of high quality standards, currently applied worldwide. If international harmonization process has aimed especially an increase in accounting figures comparability adjusting national accounting regulation towards international accounting standards, accounting convergence process focus on a single set of accounting standards for all national economies. The logic step of reducing financial reporting complexity was the orientation of the accounting standard-setters toward a principle-based philosophy, rather a rules-based model, leading to the need of a consistent conceptual framework for financial reporting that has to substitute the general accounting plan. Unfortunately, the actual IASB conceptual framework is inadequate for the actual economic system, as it is dated from 1989. There were revealed along the last decade various issues not covered by the old version of the conceptual framework. The role of the conceptual framework is not well defined (Christensen, 2010). Moreover, there were outlined several inconsistencies regarding the accounting principles versus qualitative characteristics of the financial information (Gebhardt et. al., 2014; Nobes \& Stadler, 2014). They are revealed even inconsistencies between qualitative characteristics, as is the case of using internal valuation models (Burlaud, 2013). In this case, it can't be discussed about a true and fair view of an objective reality, leading to a conflict between the faithful representation and relevance of the accounts. On these circumstances, the author considers more important the relevance of the financial information.

There was interest on revising the conceptual framework from the beginning of the IASB-FASB joint project, as it was included on the working-agenda since 2004, but with the objective of a limited revision (IASB, 2004). As this view hasn't been successful on eliminating the main international accounting differences, the two standard-setters have decided to reconsider in their agenda the project of revising the conceptual framework. On this direction, they have structured the project on 8 
Burca, V., Mates, D., Puscas, A., (2015)

Standard-setters versus Big4 opinion, concerning IASB revision project of the conceptual framework for financial reporting. The case of presentation and disclosures chapter

phases: Phase A: Objectives and qualitative characteristics, Phase B: Elements and recognition, Phase C: Measurement, Phase D: Reporting entity, Phase E: Presentation and disclosure, Phase F: Purpose and status, Phase G: Application to not-for-profit entities and Phase H: Remaining issues.

The first step was the publishing of a discussion paper (IASB, 2006). Later, an exposure draft (IASB, 2008) has been issued, referring only to the objectives of the financial statements and the qualitative characteristics of the financial information. Similarly, it was issued the DP discussing the topic of reporting entity (IASB, 2008), followed by the ED published later on (IASB, 2010). Based on the comments received on the exposure drafts, IASB has issued a revision of the conceptual framework only on the objectives of the financial statements and qualitative characteristics of the financial information. As the financial crisis has raised other financial reporting issues, IASB and FASB have decided to suspend on a temporary basis the project. For the rest of the topics, IASB has decided on 2012 to leave the old structure and considered opportune to approach all topics by issuing a single discussion paper. Moreover, after a public consultation, IASB have decided to focus especially on elements of financial statements, measurement, reporting entity, presentation and disclosure. The chapters regarding the objectives of financial statements and qualitative characteristics of financial information have not been amended by the discussion paper issued on July 2013.

The discussion paper is structured in 9 sections:

Introduction, which provided historical information about the comprehensive project of conceptual framework revision, the development, the scope, the purpose and the status of the conceptual framework, and additionally a summary of the chapters discussing the objective and qualitative characteristics.

Elements of financial statements, section which debates the problem of financial structures recognition, by addressing the problem of the existing inadequate recognition set of criteria, with a special focus on the uncertainty considerations.

Additional guidance to support the asset and liability definitions, where are proposed several changes on defining an asset or a liability and are addressed few inconsistencies between standards and the conceptual framework referring to assets or liability recognition, focusing on the meaning of economic resource, control, constructive obligation, or present obligation concepts.

Recognition and de-recognition, addressing the importance of a faithful representation of the financial position and economic performance revealed by the financial statements, with special connection to the considerations that should be accounted in case of revisions of accounting standards.

Definition of equity and distinction between liability and equity elements, raise discussion around one of the most persistent inconsistencies of the actual 
Burca, V., Mates, D., Puscas, A., (2015)

Standard-setters versus Big4 opinion, concerning IASB revision project of the conceptual framework for financial reporting. The case of presentation and disclosures chapter

conceptual framework, as nowadays the financial markets issue hybrid financial instruments that can't be always accurately classified.

Measurement chapter make connection between the objective of financial reporting and qualitative characteristics of useful financial information and the measurement requirements, addressing this approach to the three categories of measurement, namely cost-based measurements, market-based prices and cashflow based measurements.

Presentation and disclosure address the topic of optimal financial reporting, by making reference to issues like aggregation, classification and off-setting of the elements of the financial statements, materiality, communication principles, relations between the primary financial statements, or the content of the notes to the primary financial statements.

Presentation in the statement of comprehensive income bring insights from practitioners' perspective regarding setting the purpose of the statement of comprehensive income, and the connection with the income statement.

The last section, called Other issues, brings into discussion additional concepts still not clarified, such as the business model, the unit of account, the going concern concept, or the already existing concept of capital maintenance.

Currently, after long discussion regarding the feedback received through the consultation process with all interested parties, IASB has published a summary of their opinion regarding the form of the exposure draft that is expected to be issued on the second quarter of this year.

We will draw some reflections regarding IASB position on Presentation and disclosure chapter, against the position expressed in the comment letters of the international accounting firms and the regional accounting standard-setters.

Our study is aimed to analyze the measure IASB has achieved to meet the most important regional actors on implementing and enforcing IFRS. We expect different position expressed by Big4 companies versus position of regional standard-setters. This predictable as the first are in the position of certifying the financial statements, and the other could be considered just as users of financial information, with a less technical expertise.

\section{Literature review}

Initiatives on revising the current conceptual framework for financial reporting have been dated from long time ago, as it was transformed into an essential tool of achieving international accounting harmonization (Baker \& Barbu, 2009). Economy dynamics have determined deep changes in the configuration of financial information market, as the demand became more complex, while the offer has extended under the constraints of preparation and litigation costs. In order to prevent the conflictual states between preparers and users of financial information, 
Burca, V., Mates, D., Puscas, A., (2015)

Standard-setters versus Big4 opinion, concerning IASB revision project of the conceptual framework for financial reporting. The case of presentation and disclosures chapter

the conceptual framework has to give wise solutions on covering areas not addressed by existing standards and has to be the starting point of new high quality standards as well (Christensen, 2010).

Barth (2007) outline several areas where there is still space for improvement concerning:

$\checkmark$ the multitude of objectives of financial reporting;

$\checkmark$ the interconnection, conflicts and ranking of the qualitative characteristics for an useful financial information;

$\checkmark$ the uncertainty topic generating various interpretation about the limit the expected economic benefits should be considered as realizable;

$\checkmark$ the sufficiency of the existing set of criteria used on recognizing the assets and liability;

$\checkmark$ the choice for a proper measurement basis;

$\checkmark$ the boundaries of the reporting entity;

$\checkmark$ the role of the notes of the financial statements;

$\checkmark$ the limits of a healthy voluntary financial reporting etc.

The globalization process is irreversible. It is favored by the political factor and regional economic configurations making pressure towards more simplified financial reporting. Financial reporting simplification can be achieved through international accounting harmonization efforts, or compliance with the results of the international accounting convergence project (Jayaraman \& Verdi, 2013; Ramanna \& Sletten, 2014).

The question remaining unanswered in the area of the financial statements profile is what information should be disclosed on the financial statements. If it is clear that financial statements have to disclose information regarding economic resources and obligations of the reporting entity, in their static and dynamic perspective as well, there is not yet clear the way preparers have to do so. In terms of presentation and disclosure of financial information, standard-setters have to find out the proportion between mandatory financial statements and voluntary disclosures. For this accounting regulation has to address the minimum requirements in financial reporting that do not affect negatively the decisionmaking process. Standard-setters have to figure out how to make sure the preparers will disclose qualitative financial information as well, as currently voluntary disclosure are not mandatory to be certified by auditors. On this light we agree with Le Manh \& Ramond (2011) who outline four common sense principles addressed on a dual approach, that have to be consider on revising the conceptual framework: - information quality vs. information transparency, describing the focus on the quality of financial information, and not on volume of financial information disclosed; 
Burca, V., Mates, D., Puscas, A., (2015)

Standard-setters versus Big4 opinion, concerning IASB revision project of the conceptual framework for financial reporting. The case of presentation and disclosures chapter

- timing vs. timeliness of information, which reveal the effect of an opportune financial information on the investing decision, and the impact of the use of different earnings manipulation techniques on the figures reported;

- permanent vs. transitory performance measures, which lead us to reflections around the use of static performance measures, rather than performance metrics revealing evolution of the changes in the static performance measures; only this way, financial information can be tested if it is predictable or market-shocks impact assets accounting value through the fair value basis use;

- value vs. price, addressing the problem of choosing the best model used on fair value estimation, as there is a significant gap between cost-based models, cashbased models and market-based models; the decision depends on the intention the reporting entity has concerning the use of that asset (selling versus using in the operational activities).

Ohlson et. al. (2010) address as well the problem of revising the conceptual framework, considering that this tool will be useful as long as:

- it places specific restrictions on what constitutes admissible accounting standards;

- it is enough flexible, but relatively stable in time;

- address matters of setting boundaries that have to fall within the domain of standard-setters, where they are rated with enough legitimacy, as the reality proved how important are the politics of the accounting standards;

- avoids issues that raise more questions than resolve, considering opportune the inclusion of specific issues within existing revised standards, or new standards.

In the same study, the authors bring into discussion several principles that should be considered in financial reporting, which have significant impact on the content and structure of the financial statements. They have proposed a set of five additional principles into discussion, namely:

- recognition and measurement rest on interpreting transactions, which means each transaction has to be accounted based on facts, an less on estimations like is the case of measured assets and liabilities using fair value basis;

- operating activities have to be reported separately from the financial activities, as the operating activity productivity is not influenced by the financing strategy; thus, operations like leases have to be disconnected from the operating residual income; - the centrality of the operating earnings measurement, which implies the most important financial statements should be the profit and loss statements, whereas the balance sheet and the cash flow statement have to explain by their elements variation the value of the earnings reported within the P\&L statement;

- balance sheet conservatism, which recommend a conservative approach on recognizing and measuring the balance sheet structures, as there are cases when the sum of the accounting-based values of the assets, net of the liabilities, is exceeding the fair value of the business in its entirety; 
Burca, V., Mates, D., Puscas, A., (2015)

Standard-setters versus Big4 opinion, concerning IASB revision project of the conceptual framework for financial reporting. The case of presentation and disclosures chapter

- owners' equity accounting rests on a proprietorship perspective, principle which require the hybrid financial instruments have to be considered as liabilities, as owners' equity pertains to the residual interest only.

The implications of these principles on the financial statements are visible:

- the balance sheet structures would have to be divided into two main groups and mutually exclusive; moreover, the traditional historical cost measurement model should be mandatory on measuring the operating assets and liabilities, realizing a start for the preparation of the financial statement, based on two consecutive balance sheets;

- the forecasting of the future earnings will be facilitated as the income and the expenses will be split into four categories, basing on the following dual set of criteria: recurring vs. non- recurring income / expenses, and financial vs. operating income/ expenses; this way, the central performance metric should be the recurrent operating earnings;

- the residual interest of the common shareholders can be calculated more precisely starting from the period's value creation as determined by comprehensive earnings, minus the net distribution of the value to the common shareholders as determined by the common dividends and stock repurchases net of all common shareholders' capital contributions;

- cash-flow statement should look similar to the income statement, but expressed in cash terms, with emphasis on the accruals component correspondence of each cash flow.

It is obvious that the revision of the actual conceptual framework has to consider a general approach of all financial reporting issues addressed, as the conceptual framework should mainly support the issue of new financial reporting standards, not the justification for the accounting treatments preparers use. This question has been addressed within the current discussion paper too and the answers were mixed. Beyond all the opinions, it should be clear that preparers have to refer to the conceptual framework especially concerning conceptual issues. All these issues can be solved by complying with the general accepted accounting principles. But for this there must be eliminated the contradictions between accounting principles and the qualitative characteristics of the useful financial information, as the preparers always justify the accounting treatments referring rather to qualitative characteristics, than to accounting principles (Nobes \& Stadler, 2014).

Beyond all these remarks, all the efforts on configuring the format and content of the financial statements have to consider that the optimal financial reporting is a matter of isolated optimal, valid in the case of each reporting entity. Secondly, financial statements are useful, not just for the control function shareholders and stakeholders have, but especially for the decision-making process. Unfortunately, is has been observed that financial information disclosed with the financial statements 
Burca, V., Mates, D., Puscas, A., (2015)

Standard-setters versus Big4 opinion, concerning IASB revision project of the conceptual framework for financial reporting. The case of presentation and disclosures chapter

is less timely than other source of information (Christensen, 2010). This is why the approach the conceptual framework has to have regarding financial statements needs to be general, because each user has different needs. It is obvious that big part of a share-price is determined by alternative sources of information disclosed by financial statements, as they are more frequent. But, in case of debt contracting and macroeconomic accounting, the main source of information remains the information reported in the financial statements.

The importance IASB gave to this revision project is high as they have even addressed this topic on one of its research forums, held on 2014 at SAID Business School, Oxford University. The papers presented on this conference have covered not just the topic of presentation and disclosure of financial information, but the objectives of financial statements, the qualitative characteristics of useful financial information, the implications of conservative accounting, the lack of concepts in measurement, or other specific paradigms addressed by existing financial reporting standards as well. From the papers presented on this conference is it obvious the interest of researchers on continuing the debated concerning the objectives of financial statements or the qualitative characteristics of the useful financial information, even if these topics are already materialized on revised chapters of the conceptual framework dated 2010. One of the papers presented with significant impact on the presentation and disclosure of the financial information is Hopkins's study, who claims the need that standard-setters should standardize the format of the financial statements, especially with focus on the notes to the financial statements, as there is vast area for preparers to use different impression management techniques. Thus, his work is outlining the fact that the way financial information is reported influence the decision-making process. The importance given to the financial information is connected to the place the information is disclosed in the financial statements. Not the least, the topic of aggregation versus des-aggregation and the measure of the materiality of disclosed financial information have to be reconsidered. This reality is in agreement with Hirshleifer $\&$ Teoh (2003) who outlined that the format of the financial statements, especially the location of the information in the reporting package, may mislead the unexperienced investors that can't access analysts' services in their decisionmaking process.

\section{Methodology research}

The study is aimed to outline regional standard-setters versus international accounting and auditing firms' opinions concerning the topics of presentation and disclosure addressed by the current discussion paper of IASB revision of conceptual framework project. From a total number of 221 comment letters received by February 2014, we will limit our study to review 18 comment letters. 
Burca, V., Mates, D., Puscas, A., (2015)

Standard-setters versus Big4 opinion, concerning IASB revision project of the conceptual framework for financial reporting. The case of presentation and disclosures chapter

Thus, on international accounting and audit firms group, we will refer to BDO, Delloite, Mazars, Grant Thorton, KPMG, PWC and Ernst \& Young. On the other side, representative regional standard-setters we include in our sample are the members of the Accounting Standards Advisory Forum (ASAF), namely: EFRAG (European Financial Reporting Advisory Group), AOSSG (Asian-Oceanian Standard-Setters Group), SAFRSC (South African Financial Reporting Standards Council), AcSB (Canandian Accouting Standards Board), CASC (Chinese Accounting Standards Committee), AASB (Australian Accounting Standards Board), ASBJ (Accounting Standards Board of Japan), FRC (United Kingdom Financial Reporting Council) and GLASS (Group of Latin American Standard Setters).

Table 2. Questions addressed on the study

\begin{tabular}{|c|c|l|}
\hline $\begin{array}{c}\text { DP } \\
\text { question }\end{array}$ & $\begin{array}{c}\text { Study- } \\
\text { designed } \\
\text { question }\end{array}$ & \multicolumn{1}{c|}{ Definition } \\
\hline $\mathrm{Q}_{16}$ & 1 & Do you agree with the scope of the FC? \\
\hline $\mathrm{Q}_{16}$ & 2 & Do you agree with the objectives of the primary financial statements? \\
\hline $\mathrm{Q}_{16}$ & 3 & Do you agree with the scope of the primary financial statements? \\
\hline $\mathrm{Q}_{16}$ & 4 & Do you agree with equal priority within the financial statements? \\
\hline $\mathrm{Q}_{16}$ & 5 & $\begin{array}{l}\text { Are there any contradictions or redundant issues addressed on this } \\
\text { discussion paper versus the current Conceptual Framework and existing } \\
\text { standards? }\end{array}$ \\
\hline $\mathrm{Q}_{16}$ & 6 & Is it appropriate additional guidance to be included on the FC? \\
\hline $\mathrm{Q}_{16}$ & 7 & $\begin{array}{l}\text { Shall the project consider the output of other related IASB projects or } \\
\text { other organizations' projects? }\end{array}$ \\
\hline $\mathrm{Q}_{16}$ & 8 & Is there enough guidance regarding classification? \\
\hline $\mathrm{Q}_{16}$ & 9 & Is there enough guidance regarding aggregation? \\
\hline $\mathrm{Q}_{16}$ & 10 & Do you agree with off-setting treatment like is shown in this DP? \\
\hline $\mathrm{Q}_{18}$ & 11 & Is the concept of materiality well defined? \\
\hline $\mathrm{Q}_{17}$ & 12 & Is there need for additional guidance on materiality application? \\
\hline $\mathrm{Q}_{18}$ & 13 & Do you agree with the communication principles? \\
\hline $\mathrm{Q}_{18}$ & 14 & $\begin{array}{l}\text { Is it necessary to raise a new standard about principles to be used on the } \\
\text { financial disclosures? }\end{array}$ \\
\hline $\mathrm{Q}_{18}$ & 15 & $\begin{array}{l}\text { Shall disclosures on the notes to primary financial statements be } \\
\text { supplementary to the information from the financial statements? }\end{array}$ \\
\hline $\mathrm{Q}_{18}$ & 16 & Are the objectives and scope of disclosures clear enough? \\
\hline
\end{tabular}

The study will be designed to provide statistics for 16 questions addressing presentation and disclosure section topics, starting from the questions IASB has raise to the ones have submitted comment letter. The questions raise by IASB within the discussion paper are the following: 
Burca, V., Mates, D., Puscas, A., (2015)

Standard-setters versus Big4 opinion, concerning IASB revision project of the conceptual framework for financial reporting. The case of presentation and disclosures chapter

$\mathbf{Q}_{16}$. Do you agree with the IASB's preliminary views about the scope and content of guidance that should be included in the Conceptual Framework on:

(a) presentation in the primary financial statements, including: (i) what the primary financial statements are; (ii) the objective of primary financial statements; (iii) classification and aggregation; (iv) offsetting; $(v)$ the relationship between primary financial statements;

(b) disclosure in the notes to the financial statements, including: (i) the objective of the notes to the financial statements; and (ii) the scope of the notes to the financial statements, including the types of information and disclosures that are relevant to meet the objective of the notes to the financial statements, forward-looking information and comparative information.

$\mathbf{Q}_{17}$. Paragraph 7.45 describes the IASB's preliminary view that the concept of materiality is clearly described in the existing Conceptual Framework. Consequently, the IASB does not propose to amend, or add to, the guidance in the Conceptual Framework on materiality. However, the IASB is considering developing additional guidance or education material on materiality outside of the Conceptual Framework project.

Do you agree with this approach? Why or why not?

$\mathbf{Q}_{18}$. The form of disclosure requirements, including the IASB's preliminary view that it should consider the communication principles in paragraph 7.50 when it develops or amends disclosure guidance in IFRSs, is discussed in paragraphs 7.487.52 .

Do you agree that communication principles should be part of the Conceptual Framework? Why or why not? If you agree they should be included, do you agree with the communication principles proposed? Why or why not?

The answers are appreciated by us, based on each organization opinion drawn on their comment letters, with yes or no. We start the statistical analysis by considering that if a topic is not addressed by an organization, the topic is automatically agreed as IASB has addressed it on the discussion paper.

The questions will be grouped into seven subgroups, each group reflecting a major subject, like are: the topic of the disclosures, the scope and objectives of the financial statements, the way the results of the project are formalized and reconciled with the output of other similar project in progress etc.

\section{Results and discussion}

The issues concerning financial statements cover unlimited areas, as financial reporting complexity has grown over the last decades. Challenges like incorporation of the business model into the structure of annual accounts presentation, the dual treatment regarding recognition versus disclosure, or the 
Burca, V., Mates, D., Puscas, A., (2015)

Standard-setters versus Big4 opinion, concerning IASB revision project of the conceptual framework for financial reporting. The case of presentation and disclosures chapter

difficulties on addressing properly the risk assessment for the shareholders, have raised the need to reformulate corporate financial reporting configuration.

Chairman of IASB, Hans Hoogervorst, recognize the effect of the politics on the accounting standard-setting, but remain to his main objectives outlining a core set of accounting principles (KPMG, 2013). For this, IASB has decided to involve as many interested parties as possible in the accounting standard-setting process, and first have opened and Agenda of consultation revealing the most important topics to be debated by the board in the future. The project for conceptual framework revision was, also, considered. But, regarding presentation and disclosure, it was structured in a wider approach as it was interconnected with a specific project, called Disclosure Initiative. This project has started, based on the results of a survey held under a Discussion Forum regarding financial information disclosure on January 2013, which underlined the fact that the main problem of the annual reports is located not only in the financial statements, but evenly spread throughout the annual report including the notes to the financial statements, as well (IASB, 2013). Preparers and users have emphasized the problem of a poor financial communication and a lack of materiality for a significant part of the information disclosed on the annual reports. IASB decided to proceed to take action in three main areas:

- will be made some narrow scope amendments to IAS 1, in order to address perceived impediments to preparers exercising their judgement in presenting their financial reports; this part was realized on December 2014, based on the comments received by IASB on ED/2014/1 Disclosure Initiative, bringing more light on the topic of the information that should be disclosed on the notes to the financial statements; also, it explained the narrow scope for the materiality concept in connection with requirements addressed by a standard, and clarified some aspects regarding aggregation of the elements from the statement of financial position and statement of profit or loss and other comprehensive income;

- will be made some changes on IAS 7, in the direction of a better reconciliation of liabilities from financing activities and additional disclosures required to make a better understanding of entities' liquidity;

- will seek to develop educational material, on materiality topics, with input from an advisory group; for this, IASB has taken as a basic input the results of the research studies made by ESMA on finding out the perceptions and realities the practitioners face up nowadays regarding the application of the concept of materiality; they concluded that this concept is well understood, but there is still needed additional guidance because of the diversity on using it, especially in disclosures area (ESMA, 2013); 
Burca, V., Mates, D., Puscas, A., (2015)

Standard-setters versus Big4 opinion, concerning IASB revision project of the conceptual framework for financial reporting. The case of presentation and disclosures chapter

- will consider as part of its research agenda the broader challenges associated with disclosure effectiveness, separately from the project of revision of the conceptual framework:

$>$ will identify and develop a set of principles for disclosure in IFRS that could form the basis of a Standards-level project

$>$ will review disclosures in existing standards to identify and assess conflicts, duplication and overlaps. This project will be informed by the principles being developed in the Principles of Disclosure project.

Overall, this complementary project is intended to replace IAS 1, IAS 7 and IAS 8 with a IFRSs disclosure framework. Disclosure Initiative project output will be used as an input for the joint project between IASB and FASB, called Financial Statement Presentation which seeks to improve the usefulness of the financial information provided in an entity's financial statements to assist management to better communicate its financial information to the users of its financial statements, and to help users in their decision-making (IASB, 2015). This project is split into three phases:

- phase A provided the output for the amendments made on IAS 1;

- phase B consisting of three points:

$>$ IAS 1 and IAS7 replacement, which is the stage of re-deliberations of the results obtained around the discussion paper issued on October 2008, exceeding the initial due date for the exposure $\mathrm{draft}^{1}$, planned for the beginning of 2011 ;

$>$ development of a common definition of discontinued operations and set up of common disclosures that should be published, related to disposals of components of an entity; this section has been decided to be included on previous standard exposure draft;

$>$ improvement of the transparency of the reported items of other comprehensive income statement, which was completed as a part of the amendments made on IAS 1 on December 2014;

- phase $C$ relate to interim financial statements which had to be included on US GAAP; there is, also, possibility that IASB can consider opportune some changes to make on IAS 34.

On the other side, FASB has initiated a similar project, called Disclosure Framework, which main objective is to improve the effectiveness of disclosures in notes to financial statements by clearly communicating the information that is most important to users of each entity's financial statements (FASB, 2014).

The project is split in the following sections, focusing on specific disclosure topics: (i) disclosure review - defined benefit plans, currently in initial deliberation; (ii) disclosure review - fair value measurement; (iii) disclosure review- income taxes; 
Burca, V., Mates, D., Puscas, A., (2015)

Standard-setters versus Big4 opinion, concerning IASB revision project of the conceptual framework for financial reporting. The case of presentation and disclosures chapter

(iv) disclosure review - inventory; (v) disclosures - interim reporting; and (vi) disclosure framework- entity's decision process. Each review will include:

- evaluation of existing disclosure requirements within the Topic after applying the concepts in the Board's decision process;

- position promoting the appropriate use of discretion by entities specifically within the topic.

Beside this major project, FASB has started, also, projects concerning amendments that have to be made on:

- SFAS 95, meaning changes lead by providing classification guidance on certain cash receipts and cash payments;

- provisions of classification of debts in current versus non-current, in the balancesheet, that have to be taken-out.

Complex approach on this direction was underlined on EFRAG discussion paper which tried to give a more detailed guidance, proposing that:

- the disclosures in the notes should be considered as complementary to the primary financial statements; in order to improve the communication of the financial information, the study reveal some basic principles that should guide the design of the notes to the financial statements, naming here that: the disclosures should be entity-specific, they should be current, have to explain the substance of the transaction, should be organized, clear, balanced, concise and written in plain language, and have to be linked with each other;

- the notes have to focus on past transactions and other events existing at the reporting date, and to future events only in case they are strongly connected with past events;

- the business model and the strategic information, essential for investors in order to appreciate entities' sustainability, can be easily integrated (EFRAG, 2012).

FASB made visible progress on this direction as well, issuing the exposure draft of a new Statement of Financial Accounting Concepts (SFAC), called Conceptual Framework for Financial Reporting, concerning the topic of the notes to financial statements. While chapter 1 of Conceptual Framework for Financial Reporting is addressing the issue of the objectives of the financial statements, and chapter 3 reveal conceptual guidance on the qualitative characteristics of the useful financial information, chapter 8 discuss the topic of the notes to the primary financial statements. Currently, this chapter is in the exposure draft phase, being similar with IASB position, but with the remark that FASB seems to have the preference for more detailed notes.

Beyond this, we can observe the fact that the projects concerning the conceptual framework and disclosures are strongly interrelated. This means that IASB has to pay attention to prevent potential conflicts between the formalized results of the two projects, by reviewing them on an integrated approach. 
Burca, V., Mates, D., Puscas, A., (2015)

Standard-setters versus Big4 opinion, concerning IASB revision project of the conceptual framework for financial reporting. The case of presentation and disclosures chapter

IASB has received 221 comment letters on the project for conceptual framework revision by February 2014. High interest was on preparers' side as they have gathered about $38 \%$ from the total number of the comment letters, followed by academic researchers with $14 \%$, and accountancy bodies with $10 \%$, confirming the trend Jorissen et. al. (2014) have outlined about the limited interest in case of users. But, in the light of deregulation process worldwide, it is welcomed the more visible presence of the national standard-setter. There is unanimous support from all actors involved for IASB efforts on revising the current conceptual framework, with some remarks that should be considered by IASB for future:

- there is no need to finalize the project by the end of 2015, as its complexity requires more time to analyze in more details some aspects;

- the decision of building the new conceptual framework by revising the existing one is the best choice, while the existing chapters already revised, concerning the qualitative characteristics of the financial information and the objectives of the financial statements have to be just partially reviewed;

- there has to be more flexibility on conceptual framework revision, as it has to be revised on a regular basis, especially in the direction of reviewing all existing standards and standards under development in order to identify potential conflicts with the revised conceptual framework;

- separate discussion of the notes to the financial statements on a distinct IASB project is welcomed, as the conceptual framework has to set up general view of financial reporting, and avoid any attempt to go in many details, as would be the case of disclosures topic (IASB, 2014).

A general overview of the comment letters addressing the topic of presentation and disclosures lead us to the following conclusions:

- the conceptual framework should not only be used as guidance on issuing new accounting standards or revising existing ones; it should still be used as a conceptual base for preparers on financial reporting strategy design;

- the conceptual framework should not get in detail when talking about disclosure requirements guidance, as is the case of proposed examples of disclosures split by type of useful information mentioned on the actual discussion paper (DP, p. 143);

- the definition of the concept of materiality is well perceived, but there is still need for additional guidance material;

- it is opportune to include communication principles on the conceptual framework, but they have to reviewed as they are not enough to ensure efficient disclosures.

Our study limits to the opinions expressed by regional standard-setters versus international accounting firms. As concerns the scope of the conceptual framework, most of them have agreed with the scope mentioned in the issued discussion paper. But there are some who believe that the conceptual framework should be used not only in purpose of issuing future new standards and amending existing ones. The 
Burca, V., Mates, D., Puscas, A., (2015)

Standard-setters versus Big4 opinion, concerning IASB revision project of the conceptual framework for financial reporting. The case of presentation and disclosures chapter

conceptual framework should be continuously used as a reference on preparers' design of financial reporting strategies.

Figure 1

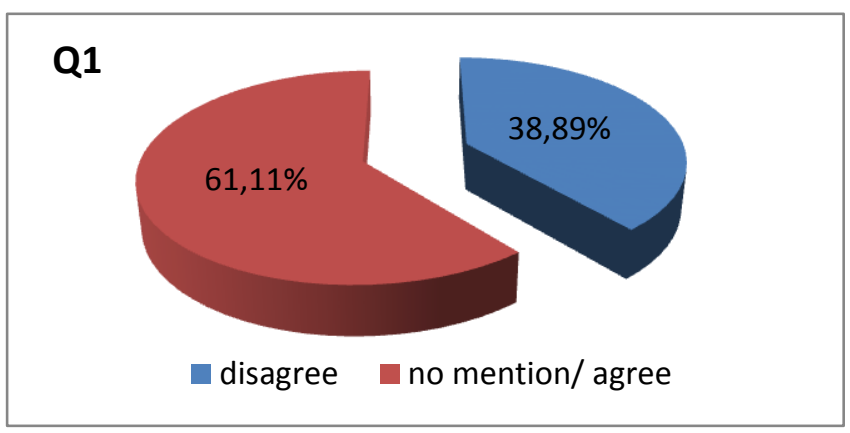

These results would be explainable as just the preparers are the ones who put pressure on continuing to use the conceptual framework as a justification basis on designing own financial reporting strategies. But, IASB position on this discussion paper seems to be in conflict with IASB 8 requirement, which state that in the absence of a standard addressing a specific event to be accounted, the practitioner has to use the professional judgment in order to disclose relevant, reliable and conservative financial information (IAS 8, par. 10).

Most of the respondents have not disagreed with the objectives of the primary financial statements, which is to provide summarized information about recognized assets, liabilities, equity, income, expenses, changes in equity and cash flows that has been classified and aggregated in a manner that is useful to users of financial statements in making decisions about providing resources to the entity (DP, $\mathrm{p}$. 137). This way, the financial statements will reflect entities' financial position, financial performances and the effectiveness and efficiency of management's strategy. The main reason against is the presentation of these objectives which seem to be too vague (KPMG, AcSB).

The scope of the primary financial statements seems to be debatable as more than $44 \%$ from the institutions, included on our sample, disagree with IASB position expressed on the discussion paper. Only 5 standard-setters have disagreed with the scope of the primary financial statements as it is too vague (EFRAG), or there can't be made clear separation between primary financial statements information versus information disclosed in the notes to the primary financial statements (AOSSG, AcSB, AASB and FRC). 


\section{STUDIA UNIVERSITATIS ECONOMICS SERIES}

"Vasile Goldiş" Western University of Arad

Burca, V., Mates, D., Puscas, A., (2015)

Standard-setters versus Big4 opinion, concerning IASB revision project of the conceptual framework for financial reporting. The case of presentation and disclosures chapter

Table 3. Positions split by standard-setter versus auditing firm

\begin{tabular}{|c|c|c|c|c|c|c|c|c|}
\hline & \multicolumn{3}{|c|}{ Count } & \multicolumn{3}{|c|}{$\%$} & \multicolumn{2}{|c|}{ Total } \\
\hline $\begin{array}{c}\text { Desagree } \\
\text { answers }\end{array}$ & $\frac{5}{0.0}$ & 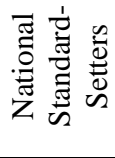 & 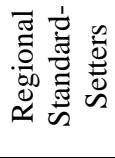 & .0 & 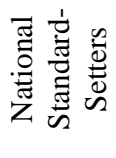 & 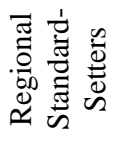 & count & $\%$ \\
\hline $\mathrm{Q}_{1}$ & 3 & 2 & 1 & $16.67 \%$ & $16.67 \%$ & $5.56 \%$ & 7 & $38.89 \%$ \\
\hline $\mathrm{Q}_{2}$ & 2 & 1 & 0 & $11.11 \%$ & $5.56 \%$ & $0.00 \%$ & 3 & $16.67 \%$ \\
\hline $\mathrm{Q}_{3}$ & 0 & 3 & 3 & $0.00 \%$ & $16.67 \%$ & $16.67 \%$ & 6 & $33.33 \%$ \\
\hline $\mathrm{Q}_{4}$ & 0 & 1 & 1 & $0.00 \%$ & $5.56 \%$ & $5.56 \%$ & 2 & $11.11 \%$ \\
\hline $\mathrm{Q}_{5}$ & 6 & 4 & 2 & $33.33 \%$ & $22.22 \%$ & $11.11 \%$ & 12 & $66.67 \%$ \\
\hline $\mathrm{Q}_{6}$ & 4 & 3 & 3 & $22.22 \%$ & $16.67 \%$ & $16.67 \%$ & 10 & $55.56 \%$ \\
\hline $\mathrm{Q}_{7}$ & 0 & 5 & 3 & $0.00 \%$ & $27.78 \%$ & $16.67 \%$ & 8 & $44.44 \%$ \\
\hline $\mathrm{Q}_{8}$ & 0 & 2 & 0 & $0.00 \%$ & $11.11 \%$ & $0.00 \%$ & 2 & $11.11 \%$ \\
\hline $\mathrm{Q}_{9}$ & 1 & 2 & 1 & $5.56 \%$ & $11.11 \%$ & $5.56 \%$ & 4 & $22.22 \%$ \\
\hline $\mathrm{Q}_{10}$ & 0 & 2 & 0 & $0.00 \%$ & $11.11 \%$ & $0.00 \%$ & 2 & $11.11 \%$ \\
\hline $\mathrm{Q}_{11}$ & 2 & 1 & 2 & $11.11 \%$ & $5.56 \%$ & $11.11 \%$ & 5 & $27.78 \%$ \\
\hline $\mathrm{Q}_{12}$ & 2 & 2 & 1 & $11.11 \%$ & $11.11 \%$ & $5.56 \%$ & 5 & $27.78 \%$ \\
\hline $\mathrm{Q}_{13}$ & 2 & 2 & 1 & $11.11 \%$ & $11.11 \%$ & $5.56 \%$ & 5 & $27.78 \%$ \\
\hline $\mathrm{Q}_{14}$ & 7 & 4 & 3 & $38.89 \%$ & $22.22 \%$ & $16.67 \%$ & 14 & $77.78 \%$ \\
\hline $\mathrm{Q}_{15}$ & 2 & 1 & 1 & $11.11 \%$ & $5.56 \%$ & $5.56 \%$ & 4 & $22.22 \%$ \\
\hline $\mathrm{Q}_{16}$ & 3 & 5 & 2 & $16.67 \%$ & $27.78 \%$ & $11.11 \%$ & 10 & $55.56 \%$ \\
\hline
\end{tabular}

Source: own calculation

Figure 2

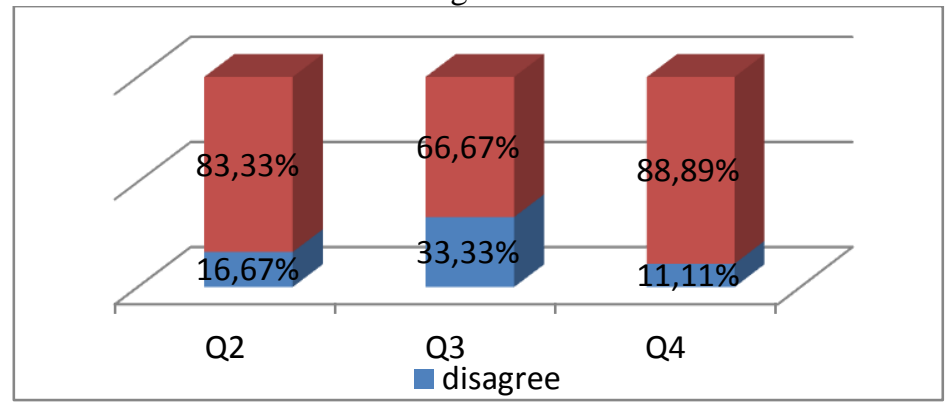

Predictable is respondents' opinion regarding the prioritization of the financial statements, which seem to consider more suitable all financial statements should be equally important in the case of more than $88 \%$ of the respondents. Only AOSSG and ASBJ are against this position, as cash flow statement can't reply properly to the decision-making process as the information would not be predictable, the production factors' productivity can't be calculated accurately and the list can 
Burca, V., Mates, D., Puscas, A., (2015)

Standard-setters versus Big4 opinion, concerning IASB revision project of the conceptual framework for financial reporting. The case of presentation and disclosures chapter

continue. As long as entities operate with commercial credits, and any other longterm financing scheme, there will be need of accruals in order to fulfil the requirements necessary to disclose by financial statement a true and fair view of entity's financial statements.

Figure 3

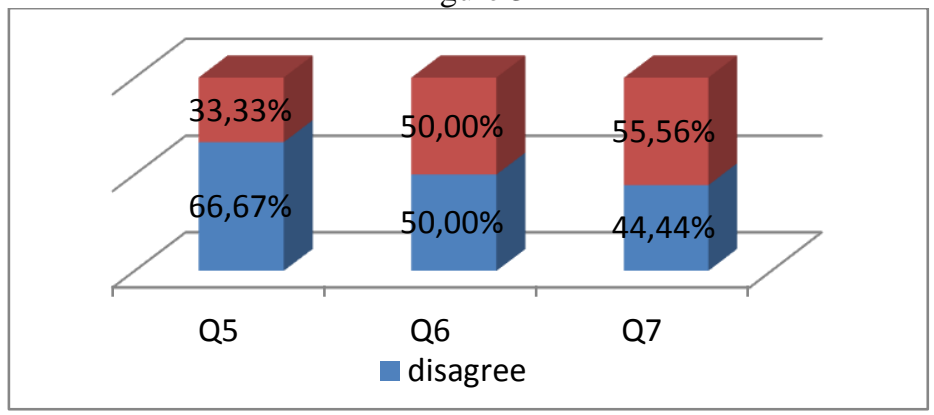

It seems that, based on our sample of comment letters, the fact that there are contradictions and redundant issues addressed on this discussion paper, comparing with existing accounting standards, seem not to worry most of the respondents. The risk would be that professionals' judgment can lead to contradictions regarding the same provision included on different standards. This can determine reduction on financial reporting standards and conceptual framework credibility.

Question 6 underlines, again, the fact that the discussion paper seems to be too vague and more guidance is needed. Here the opinions are balanced as half of the respondents prefer IASB to issue new accounting standards in order to give more guidance in various discussed topics, while the other half consider opportune the conceptual framework should be more detailed on guidance. But, the last ones refer especially the conceptual framework has to give more guidance on the application of different basic concepts IFRS use.

IASB has started numerous projects revising existing standards which are sometimes concurrent with projects issuing new standards. It is the case of the conceptual framework as well, as I described in the previous sections. Within our sample, it seems that there is not any clear preference, with a relative balance towards an integrated approach, considering useful the output from other connecting projects to be considered on the revision of the conceptual framework, too. We subscribe to this direction as this would ensure avoiding any potential conflicts between the revised conceptual framework and existing standards or standards under developments. The only problem remain in this case is the timeframe necessary to finish a project, because not only once, preparers, 
Burca, V., Mates, D., Puscas, A., (2015)

Standard-setters versus Big4 opinion, concerning IASB revision project of the conceptual framework for financial reporting. The case of presentation and disclosures chapter

researchers and users claimed the significant gap of dynamics between accounting systems and economic systems (Nobes, 2008).

On the other side, IASB has not to rush on issuing standards in order to ensure a relative stability in matter of financial reporting regulation. Otherwise frequent changes will highly impact financial statements comparability, and managers' opportunity to smooth the earnings (Capkun et. al., 2012).

Figure 4

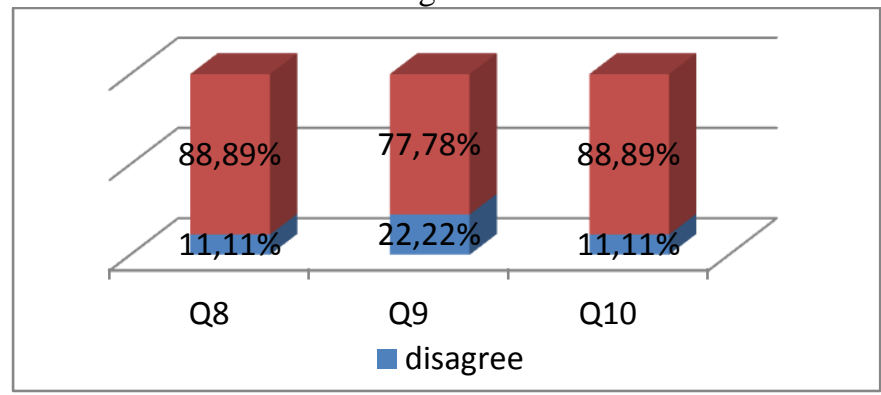

Standard-setters and international accounting firms as well do not seem to disagree to the fact that the guidance on classification and aggregation on the discussion paper is enough. Similar is the situation for offsetting principles, as respondents partially agree, and most of them omit to comment. Or maybe they still do not realize the importance and the implications that might occur on financial ratio analysis.

Similar to FASB position ${ }^{2}$, IASB consider that the following set of criteria is relevant and efficient ${ }^{3}$ :

- the function of the item - that is, the primary activities

- the nature of the item-that is, the economic characteristics or attributes that differentiate between items that respond differently to similar economic events;

- how the item is measured.

Only AASB and FRC have outlined small guidance on these topics, representing two accounting systems with capitalized markets and preference for the income statements, rather than the balance-sheet. This might be linked to the minimum requirements asked by IAS 1 on each of these financial statements, as the minimum information to be presented in the balance-sheet can be considered sufficient for a minimal solvability analysis, while in the income statements they are required just aggregated information about revenue, expenses, gain and losses (IAS 1, par. 82). This topic seem to be more important for preparers and shareholders/debtholders, than is for auditors and standard-setters, as the principles and guidance on these issues affect especially contractual covenants used on debt contracting or managers compensation 
Burca, V., Mates, D., Puscas, A., (2015)

Standard-setters versus Big4 opinion, concerning IASB revision project of the conceptual framework for financial reporting. The case of presentation and disclosures chapter

Figure 5

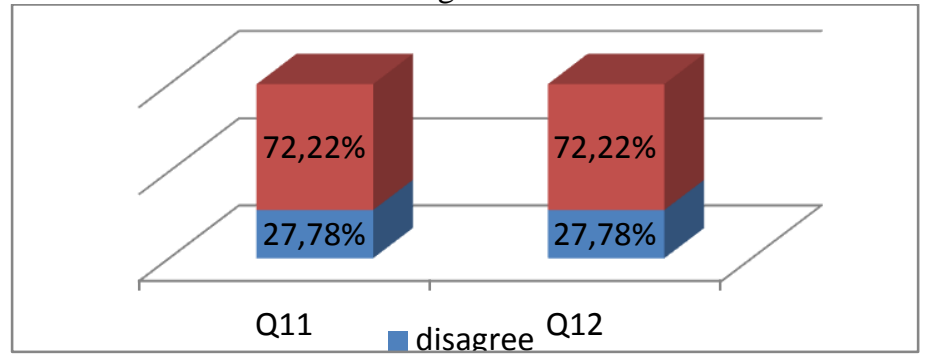

As regards the concept of materiality, the respondents agree in most part that the concept is well defined on the discussion paper, but there still is necessary additional educational guidance, which might come for each domain from professional organizations. More than that, some of the standard-setters (EFRAG, AASB, AOSSG) consider opportune IASB should issue a new standard concerning materiality of financial information to be disclosed, or start working together with other international organizations like IOSCO, or IAASB, This is because materiality definition cannot reflect all domains' special characteristics. For instance we can't compare the impact of operating leases in case of companies that have main activity renting cars, with the impact on manufacturing company using the assets for logistic operations only.

Figure 6

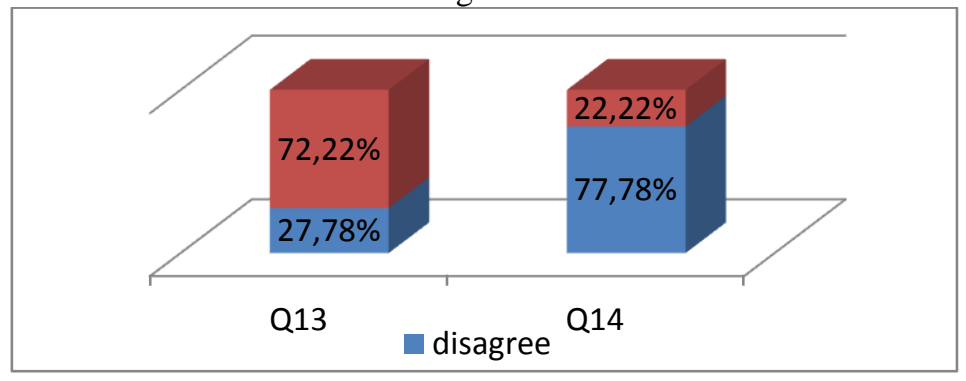

On our opinion, with regard to the changes that might come on the financial statements content and structure, the actual discussion paper brought the most changes on the area of disclosures that should be included on the notes to the financial statements. The only remark we have here is that IASB has to make sure a future potential disclosures framework should be reconciled with the revised conceptual framework as both address this topic significantly. 
Burca, V., Mates, D., Puscas, A., (2015)

Standard-setters versus Big4 opinion, concerning IASB revision project of the conceptual framework for financial reporting. The case of presentation and disclosures chapter

Most of the comment letters agree with including a set of communication principles on the text of the conceptual framework, especially when is made reference to the way the information on the notes to the financial statements is presented. These communication principles are actually the ones proposed on the study Towards a Disclosure Framework for the Notes to the financial statements (EFRAG, 2012).

Figure 7

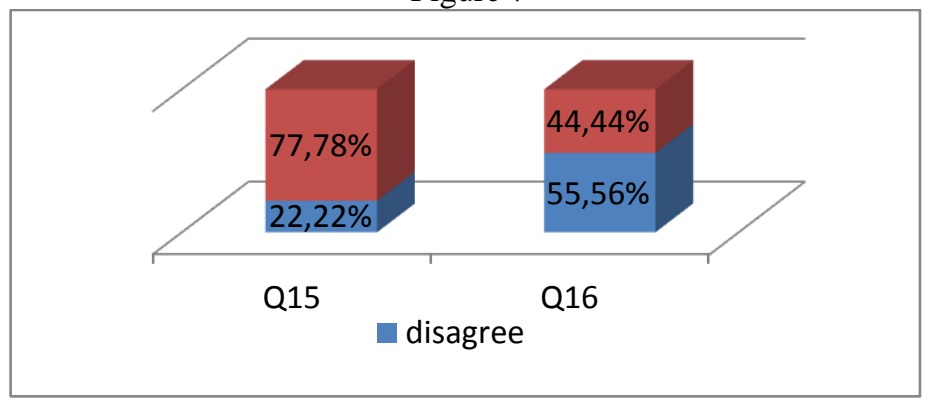

But, when asking about the way these principles to be incorporated on a separate new standards, most of the standard-setters and the auditing firms consider there is not necessary such effort. These principles have to remain either on the conceptual framework for financial reporting, or on the future disclosures framework, as they have to express a general direction for the managers when they design the disclosures included on the notes to the financial statements.

It is obvious how useful the disclosures would be for the user of the financial information, especially for the ones that could not access analysts' services by various reasons, and are less experimented on financial statements analysis. The main issue on the case of the disclosures included on the notes to the primary financial statements is their credibility, as they are not subject to the audit mission. This is why such a small percentage of only about $22 \%$ from the organizations disagree with IASB position that the notes disclose just additional information to the primary financial statements, not complementary financial information. As long as the aggregation criteria used is too vague, there will surely exist the risk that relevant information to be disclosed on the notes to the financial statements, while irrelevant information can be included on the primary financial statements.

Additionally, the format of these disclosures is not fixed, which will affect their understandability. This can be seen on last question responses profile, where the scope and the objectives of the disclosures are strongly debated. This situation is justifiable as even on EFRAG study it was mentioned that the disclosures have to be entity-specific, meaning each disclosure should have its own objective. Moreover, IASB has vaguely formulated the scope of these disclosures, in order to 
Burca, V., Mates, D., Puscas, A., (2015)

Standard-setters versus Big4 opinion, concerning IASB revision project of the conceptual framework for financial reporting. The case of presentation and disclosures chapter

prevent setting-up any limit, considering for the new standards and in case of revision of existing standards the following information that normally should be disclosed ${ }^{4}$ :

- information about the reporting entity as a whole, to the extent necessary to understand: (i) the assets, liabilities, equity, income, expenses, changes in equity and cash flows of the entity; and (ii) how effectively the entity's management and governing board have discharged their responsibilities to use the entity's assets;

- the amounts recognized in the entity's primary financial statements, including changes in those amounts, for example, disaggregation of line items, roll-forwards and reconciliations;

- the nature and extent of the entity's unrecognized assets and liabilities;

- the nature and extent of risks arising from the entity's assets and liabilities (whether recognized or unrecognized);

- the methods, assumptions and judgments and changes in those methods, assumptions and judgments, that affect amounts presented or otherwise disclosed.

If IASB will try to standardize the disclosures, they will lead decrease of the value relevance of the information disclosed on the notes to the financial statements. On this case, the materiality concept should be defined for each type of disclosure in strong connection with the objective and the scope of that disclosure.

Currently, IASB has made some tentative decisions that will be considered on the future exposure draft. On the area of presentation and disclosures, they have concluded that (IASB, 2015):

- the objectives of the primary financial statements have to remain as prescribed by chapter 3 of the objective of financial statements is to provide information about an entity's assets, liabilities, equity, income and expenses that is useful to users of financial statements in assessing the prospects for future net cash inflows to the entity and in assessing management's stewardship of the entity's resources. As a result, financial statements provide information about the financial position, financial performance and cash flows of an entity;

- the notes to the financial statements have to be considered as supplement to the financial statements, meant to ensure an increase in relevance for the financial information;

- disclosures should normally refer to: information regarding off balance-sheet accounts; forward-looking information ${ }^{5}$; disaggregated information disclosed on the primary financial statements and reconciliations; methods, assumptions, judgments and changes of methods;

- include the communication principles, in order to improve financial transparency; will not be included a discussion about financial statements in electronic format ${ }^{6}$; - the notion of primary financial statements will not be considered on the exposure draft; 
Burca, V., Mates, D., Puscas, A., (2015)

Standard-setters versus Big4 opinion, concerning IASB revision project of the conceptual framework for financial reporting. The case of presentation and disclosures chapter

- discuss disclosures requirements that should be considered on issuing new standards concerning the topic of disclosures, or in case of amendments to existing standards; there will, also, be eliminated the attempt on giving examples of disclosures that can be included on the notes to the financial statements; the only exception on this direction would be the disclosures required to assess the risks an entity face with, and to asses forward-looking information reliability;

- will not consider the discussion whether the objective of disclosure should include the provision of information that enables a user of financial statements to recalculate the amounts recognized in the financial statements.

On this perspective, IASB has to review its opinion regarding disclosures in order to reconcile actual discussion paper with previous work as is the case of the IFRS Practice Statement Management Commentary ${ }^{7}$ addressing the problem of management disclosures, meant to include strategic information, and aspects of stewardship that have to be shared as the best practices on corporate governance recommend (IASB, 2010).

\section{Conclusions}

Nowadays we assists to real changes on the definition of financial reporting, spreading along the entire financial reporting supply chain, and involving not the just the preparers or the users of the financial information. IASB has assumed the central role on coordinating the efforts to revise actual configuration of the financial statements, in strong relation with the corporate financial reporting (Zeff, 2007). They have realized that every figure disclosed on the financial statements has its story behind, and the users have to have some clues about it in order to properly understand its meaning for the decision-making process.

For this the international accounting standard-setter, together with the national accounting standard-setters have chosen the way towards an acceptable level of international accounting convergence, with main output coming from the joint project of convergence conducted by IASB and FASB. In order to issue standards of high quality, they have realized the need of revising the actual conceptual framework for financial reporting. The main goal of this project was to reduce as much as possible the complexity of the corporate financial reporting, including the annual accounts. But this would have happened only if the efforts have been structured on an integrated approach, considering improvement on financial statements and financial disclosures as well, capturing not only the financial perspective, but the social and environmental perspectives as well.

The issues raised are various as there can't be set up a fixed limit between what has to be recognized in the financial statements and what has just to be disclosed on the notes to the financial statements. Even if most of preparers and users of the financial statements consider that the notes are really important on the decision- 
Burca, V., Mates, D., Puscas, A., (2015)

Standard-setters versus Big4 opinion, concerning IASB revision project of the conceptual framework for financial reporting. The case of presentation and disclosures chapter

making process, there are studies revealing the fact that the preferred source is the primary financial statements. This trap would impact significantly especially the users of the financial information that can't access analysts' expertize and do not have enough knowledge in the area of financial reporting analysis, as the preparers will make use of different narrative disclosures.

The actual discussion paper developed under the project for revising the conceptual framework has raised debate in various areas, including the topic of presentation and disclosures. Overall, all the organizations and firms included on the sample of this study welcomed IASB efforts on this direction. But there is still need for some improvements that have to be considered on the future exposure draft planned for the Q2 2015, as would be: the need of additional guidance on classification, aggregation and offsetting the elements of the financial statements, the criteria used making separation between information to be disclosed on the financial statements versus disclosures, the prevention of potential future conflict between current standards and the revised conceptual framework, and the ways of ensuring a continuous adjustment of the financial reporting to the dynamics of the economic system.

Overall, the organizations and firms included on our sample have positively perceived IASB work on revising the conceptual framework, but had several remarks around the narrow scope of the revised conceptual framework, IASB vague position regarding clear delimitation between financial information reported on the financial statements versus disclosures, relative small guidance on the classification, aggregation and offsetting of the financial statements elements, and not the least the way the results of this project will be corroborated with linked projects like Disclosure Initiative, or Financial Statement Presentation.

It is obvious that the evolution of financial reporting is irreversible under the pressure of the process of globalization. It seems that the preferred solution for reducing financial reporting complexity is the support for the project of international accounting convergence. But there just have to be paid attention to the risk of relaxing financial reporting requirements in the service of disclosing a faithful representation of financial situation of an entity, because they will be affected other qualitative essential characteristics as is the comparability of the financial information.

\section{References}

1. Armstrong C.S., Guay W.R., Weber J.P. (2010), The role of information and financial reporting in corporate governance and debt contracting, Journal of Accounting and Economics, vol. 50, issue 2-3;

2. Baker C.R. \& Barbu E.M. (2009), Trends in research on international accounting harmonization, Accounting Theory, vol. 4; 
Burca, V., Mates, D., Puscas, A., (2015)

Standard-setters versus Big4 opinion, concerning IASB revision project of the conceptual framework for financial reporting. The case of presentation and disclosures chapter

3. Barth M.E. (2007), Research, Standard Setting, and Global Financial Reporting, Foundations and Trends in Accounting, vol. 1, issue 2;

4. Burlaud A. (2013), Should Financial Statements Represent Fairly or be Relevant? Considering the IASC/IASB Conceptual Framework, working paper;

5. Capkun V., Hammeri A., Weiss L. (2009), Does Adoption of IAS/IFRS Deter Earnings Management, available on http://hal-hec.archives-ouvertes.fr/hal-00675047;

6. Christensen H.B., Lee E., Walker M., Zeng C. (2014), Incentives or Standards: What Determines Accounting Quality Changes around IFRS Adoption?, European Accounting Review, vol. 24, issue 1;

7. Christensen J. (2010), Conceptual framework of accounting from an information perspective, Accounting and Business Research, vol. 40, issue 3;

8. EFRAG (2012), Towards a Disclosure Framework for the Notes to the financial statements, available on www.efrag.org;

9. EFRAG (2014), Getting a Better Framework. Complexity Bulletin, available on www.efrag.org;

10. ESMA (2013), Feedback Statement. Considerations of materiality in financial reporting, available on www.esma.europa.eu;

11. FASB (2014), Memorandum. Conceptual Framework-Presentation, available on www.fasb.org;

12. Gebhardt G., Mora A., Wagenhofer A. (2014), Revisiting the Fundamental Concepts of IFRS, Abacus, vol. 50, issue 1;

13. Hirshleifer D. \& Teoh S.H. (2003), Limited attention, information disclosure, and financial reporting, Journal of Accounting and Economics, vol. 36;

14. IASB (2004), Conceptual framework proposal, available on www.ifrs.org;

15. IASB (2010), IFRS Practice Statement Management Commentary. A framework for presentation, available on www.ifrs.org;

16. IASB (2013), Discussion Forum-Financial Reporting Disclosure Feedback Statement, available on www.ifrs.org;

17. IASB (2014), Conceptual Framework: High level overview of feedback on the Discussion Paper, available on www.ifrs.org;

18. IASB (2015), Effect of Board redeliberations on DP A Review of the Conceptual Framework for Financial Reporting, available on www.ifrs.org;

19. IIRC (2013), The International Integrated Reporting Framework, available on www.iirc.org;

20. Jayaraman S. \& Verdi R.S. (2013), The Effect of Economic Integration on Accounting Comparability: Evidence from the Adoption of the Euro, working paper, available on www.ssrn.com;

21. Jorissen A., Lybaert N., Orens R., van der Tas L. (2014), Constituents' Participation in the IASC/ IASB's due Process of International Accounting Standard Setting: A Longitudinal Analysis, chapter included on Accounting and Regulation. New Insights on Governance, Markets and Institutions, Springer, New York;

22. KPMG (2013), The future of corporate reporting: towards a common vision, available on www.kpmg.com; 
Burca, V., Mates, D., Puscas, A., (2015)

Standard-setters versus Big4 opinion, concerning IASB revision project of the conceptual framework for financial reporting. The case of presentation and disclosures chapter

23. Le Manh A. \& Ramond O. (2011), Determining a Consistent set of Accounting and Financial Reporting Standards. A research note based on the IASB-FASB Conceptual Framework revision project, working paper presented to the $32^{\text {th }}$ Congres of AFC, Montpellier, France;

24. Nobes C. \& Parker R. (2008), Comparative International Accounting, Prentice Hall, Edinburg;

25. Nobes C.W. \& Stadler C. (2014), The qualitative characteristics of financial information and managers' accounting decisions: evidence from IFRS policy changes, working paper presented to IFRS Research Forum 2014, held on 2 October 2014;

26. Ohlson J.A., Penman S., Bloomfield R., Christensen T.E., Colson R., Jamal K., Moehrle S., Previts G., Stober T., Sunder S., Watts R.L. (2010), A Framework for Financial Reporting Standards: Issues and Suggested Model, Accounting Horizons, vol. 24, issue 3;

27. Pompian M.M. (2006), Behavioral Finance and Wealth Management. How to build Optimal Portfolios that Account for Investors Biases, Wiley New Jersey;

28. Ramanna K. \& Sletten E. (2014), Network Effects in Countries' Adoption of IFRS, Accounting Review, vol. 89, issue 4;

29. Stephen A. Zeff (2012), The Evolution of the IASC into the IASB, and the Challenges it Faces, The Accounting Review, vol. 87, issue 3.

\section{Notes:}

${ }^{1}$ currently there is a draft for the exposure draft, named as Staff Draft of Exposure Draft IFRS X Financial Statement Presentation, dated 1 July 2010, which still has to be reconsidered;

${ }^{2}$ except the consideration regarding measurements which are not included on FASB set of criteria;

${ }^{3}$ discussion Paper, par. 7.26

${ }^{4}$ discussion Paper, par. 7.35

${ }^{5}$ forward-looking information would be included in the notes to the financial statements if it provides relevant information about existing assets and liabilities, or about assets and liabilities that existed during the reporting period;

${ }^{6}$ even though, there is enough interest IASB has shown on facilitating the use of XBLR on financial reporting, developing consistent specific taxonomy on this direction;

${ }^{7}$ it is not a standard, just material guidance; on this type of disclosure, managers have the opportunity to explain the circumstances management decisions were made, like: (a) the nature of the business; (b) management's objectives and its strategies for meeting those objectives; (c) the entity's most significant resources, risks and relationships; (d) the results of operations and prospects; and (e) the critical performance measures and indicators that management uses to evaluate the entity's performance against stated objectives. 